\title{
Cronologias da infância e disputas de representações em textos eclesiásticos e jurídicos no Brasil Império
}

Competing representations about chronologies of

childhood in ecclesiastical and legal texts in the Empire of Brazil

JUAREZ JOSÉ TUCHINSKI DOS ANJOS (DiD

aUniversidade de Brasília (UnB), Brasília, DF, Brasil. Doutor em Educação, e-mail: juarezdosanjos@unb.br. Orcid: https://orcid.org/0000-0003-4677-5816

Rev. Caminhos da Educação: diálogos, culturas e diversidades, Teresina, v. 2, n. 1, p. 5-25, jan./abr. 2020 


\title{
Resumo
}

Na medida em que a historiografia compreende a infância como uma construção social sobre um período da vida humana que informa as experiências concretas de ser criança na história (CUNNINGHAN, 1997), torna-se relevante estudar como, em determinados contextos, se procurou delimitar cronologicamente a sua duração e, de que maneira, diferentes instituições, ao produzirem sobre ela distintas representações (CHARTIER, 2002), disputaram para si esse tempo da vida. Assim, valendo-se da noção de lutas de representações (CHARTIER, 2002), o objetivo do artigo é identificar as representações sobre as cronologias da infância presentes em textos eclesiásticos e jurídicos em circulação no Brasil Império, evidenciando como disputavam entre si e eram postas a serviço dos interesses da Igreja e do Estado, formados, então, por três grupos distintos: os regalistas, os liberais e os ultramontanos. Utilizando-se a metodologia histórica, as fontes interrogadas são as Constituições Primeiras do Arcebispado da Bahia e o Abecedário Jurídico, de Carlos Antonio Cordeiro. As conclusões, num primeiro momento, apontam que as cronologias encontradas praticamente coincidem entre si, sendo a infância, para a Igreja e o Estado, o período da vida da criança que ia do nascimento aos doze/catorze anos (no caso de meninas/meninos). Todavia, um olhar aprofundado deixa entrever que a Igreja, por meio das cronologias que propunha, conseguia manter-se mais presente e influente na vida das famílias e das crianças, na medida em que através de uma série de subdivisões e responsabilidades, preenchia com inúmeras especificidades todo o tempo da vida da criança que procurava delimitar.

Palavras-chave: Brasil Império. Cronologias da Infância. História da Infância. Século XIX.

\begin{abstract}
As historiography understands childhood as a social construct about a period of human life that informs the concrete experiences of being a child in history (CUNNINGHAN, 1997), it is important to study how its duration has been chronologically delimited in certain contexts, as well as how distinct institutions have disputed such time of life by producing distinct representations about it (CHARTIER, 2002). Thus, using the notion of struggles for representations (CHARTIER, 2002), this paper aims at identifying the representations about the chronologies of childhood observed in ecclesiastical and legal texts published in the Empire of Brazil, evidencing how they competed among themselves and how they were used to serve the interests of the Church and the State, being formed by three distinct groups: the regalists, the liberals, and the ultramontanes. Using the historical methodology, the investigated sources are the Constituições Primeiras do Arcebispado da Bahia and the Abecedário Jurídico by Carlos Antonio Cordeiro. At first, the conclusions point out that the chronologies observed virtually coincide with each other; the Church and the State considered childhood as being the period of life from birth to twelve/fourteen years old (for girls/boys). However, an in-depth look reveals that the Church, through its proposed chronologies, was able to remain more present and influential in the life of families and children; through a series of subdivisions and responsibilities, they filled with a number of specificities the whole lifetime of the children that they were seeking to delimit.
\end{abstract}


Keywords: Empire of Brazil. Chronologies of childhood. History of Childhood. 19th Century.

\section{Resumen}

En la medida en que la historiografía entiende la infancia como una construcción social sobre un período de la vida humana que informa las experiencias concretas de ser un niño en la historia (CUNNINGHAN, 1997), es relevante estudiar cómo, en ciertos contextos, se buscó delimitar cronológicamente su duración y cómo diferentes instituciones, al producir diferentes representaciones de la misma (CHARTIER, 2002), disputaron para si esta época de la vida. Así, utilizando la noción de luchas de representaciones (CHARTIER, 2002), el objetivo de este artículo es identificar las representaciones de cronologías infantiles presentes en textos eclesiásticos y legales en circulación en el Imperio de Brasil, mostrando cómo disputaban entre sí y se ponían al servicio de los intereses de la Iglesia y el Estado, formados entonces por tres grupos distintos: los regalistas, los liberales y los ultramontanos. Utilizando la metodología histórica, las fuentes cuestionadas son las Constituições Primeiras do Arcebispado da Bahia y el Abecedário Jurídico de Carlos Antonio Cordeiro. Las conclusiones, al principio, señalan que las cronologías encontradas prácticamente coinciden entre sí, siendo la infancia, para la Iglesia y el Estado, el período de la vida del niño que transcurrió desde el nacimiento hasta los doce / catorce años (en el caso de niñas / niños). Sin embargo, una mirada profunda revela que la Iglesia, a través de sus cronologías propuestas, pudo permanecer más presente e influyente en la vida de las familias y los niños, ya que a través de una serie de subdivisiones y responsabilidades se llenó de innumerables especificidades todo el tiempo en la vida del niño que buscaba delimitar.

Palabras clave: Imperio de Brasil. Cronologias de la infancia. Historia de la infancia. Siglo XIX.

\section{Introdução}

$\mathrm{Na}$ medida em que a historiografia recente vem compreendo a infância como uma construção social sobre um período da vida humana, que informa as experiências concretas de ser criança em cada época da história (CUNNINGHAN, 1997; HEYWOOD, 2004; KULHMANN JR. e FERNANDES, 2004), torna-se relevante o problema histórico de como, em determinados contextos, se procurou delimitar cronologicamente a sua duração e, de que maneira, diferentes instituições, ao produzirem sobre ela distintas representações -“esquemas intelectuais incorporados que criam figuras graças às quais o presente pode adquirir sentido, o outro tornar-se inteligível e o espaço ser decifrado" (CHARTIER, 2002, p. 17) -, disputaram para si 
esse tempo da vida humana; tempo social e geracional o qual, na esteira do pensamento humanista e depois iluminista acerca da educabilidade dos pequenos (ARIÈS, 1978; VARELA, 1986; ANJOS, 2016), era tido como o mais adequado para a educação do adulto que a criança um dia viria a ser.

Egle Becchi e Ângelo Semeraro consideram que a delimitação da duração da infância é aspecto ineliminável para a pesquisa histórica (BECCHI; SEMERARO, 2001, p. X), uma vez que possibilita ler e compreender esse constructo como uma etapa cronológica na sua relação com as outras fases da vida e outros fenômenos sociais. Sobre esse ponto, José Gonçalves Gondra faz um lembrete oportuno para quaisquer historiadores que desejem embrenhar-se pelo labirinto que é a construção das idades da infância ao longo da História: “não é o caso de arbitrar sobre o arbitrário" (GONDRA, 2010, p. 209), ou seja, de esperar chegar-se a uma definição mais acurada ou próxima da realidade que outras. Antes, trata-se de compreender que aquilo que se estará investigando insere-se no campo das chamadas lutas de representações, que, segundo Roger Chartier

... têm tanta importância como as lutas econômicas, para compreender os mecanismos pelos quais um grupo impõe ou tenta impor a sua concepção do mundo social, os valores que são os seus, e o seu domínio. Ocupar-se dos conflitos de classificações ou de delimitações, não é, portanto, afastar-se do social - como julgou durante muito tempo uma história de vistas demasiado curtas - muito pelo contrário, consiste em localizar os pontos de afrontamento, tanto mais decisivos quanto menos imediatamente materiais (CHARTIER, 2002, p. 17)

Como já demonstrado em outro estudo (ANJOS, 2015), em torno da educação da criança pela família no Brasil Imperial (1822-1889), desenrolou-se uma dessas lutas de representações, tendo por contendores a Igreja Católica e o Estado Imperial e como uma das frentes de embate a demarcação das cronologias da infância. Embora durante o regime monárquico Igreja e Estado tenham se mantido constitucionalmente unidos por força do padroado régio ${ }^{1}$ e do regalismo ${ }^{2}$, com o

\footnotetext{
${ }^{1}$ Denomina-se Padroado Régio o acordo entre a Coroa e a Santa Sé segundo o qual, em troca da manutenção financeira da instituição católica vir custeada pelos cofres públicos, a nomeação dos bispos e a publicação das bulas papais em território brasileiro, por sua vez, tornavam-se um privilégio do Imperador. Isso, escreve Oliveira Lima, contribuiu para que a Igreja fosse, "em muitos Rev. Caminhos da Educação: diálogos, culturas e diversidades, Teresina, v. 2, n. 1, p. 5-25, jan/abr, 2020
} 
avanço das ideias ultramontanas ${ }^{3}$ entre os bispos brasileiros e de um crescente desejo de laicidade que começou a ser partilhado por políticos e intelectuais de meados do Oitocentos em diante, essas instituições, aos poucos, começaram a ter claras as diferenças entre si, manifestas em três tipos de representações produzidas por grupos distintos dentro delas.

Um primeiro grupo, formado por políticos e clérigos regalistas, defendia a união do Estado com a Igreja, submetendo-a aos interesses políticos, utilizando a doutrina religiosa como instrumento ideológico de produção de condições de governabilidade do Estado recém-independente. Um segundo grupo, integrado inicialmente por bispos ultramontanos e acrescido, posteriormente, pelo clero por eles preparado em Seminários reformados de acordo com as normas do Concílio de Trento, intentava, por um lado, submeter o Estado à Igreja, buscando uma maior fidelidade às diretrizes romanas e autonomia face às ingerências do poder temporal na instituição eclesiástica. Por outro lado, queria fazê-lo sem romper com o Estado, já que o Império, segundo a Constituição de 1824, era católico, o que paradoxalmente, resultava numa posição confortável da qual a hierarquia católica não queria abdicar. Por fim, um terceiro grupo, constituído por políticos e intelectuais de formação jurídica e interessados na aplicação das ideias liberais clássicas, temperadas, nas décadas finais do Império, com pitadas de cientificismo, positivismo e anticlericalismo, defendia a necessidade de uma separação (ou, no caso dos menos exaltados, uma menor dependência) entre Igreja e Estado, de modo que este se afirmasse como instituição organizadora da vida social, pelo respeito às leis e aos direitos e deveres a partir dela elaborados, com vistas à produção de coesão e

pontos, serva do Estado, estando o clero sob sua alçada em matéria da doutrina e do culto" (OLIVEIRA LIMA, 1986, p. 142).

${ }^{2} \mathrm{O}$ Regalismo foi a doutrina política segundo a qual o Soberano tinha o direito de intervir na vida da Igreja Católica do seu país, o que resultava na submissão dessa instituição ao Estado. Tal doutrina, em Portugal, consolidou-se durante o governo de D. José I (1750-1777) e manteve-se, no Brasil, como herança da Colonização. Foi largamente utilizado pelo Estado imperial e seus agentes.

3 O movimento ultramontano, desencadeado por bispos reformadores brasileiros do século XIX, teve por características gerais, conforme Ivan Manoel, “...na esfera intelectual, a rejeição à filosofia racionalista e à ciência moderna; na política externa, a condenação à liberal democracia burguesa e o concomitante reforço da ideia monárquica; na política interna, o centralismo em Roma e na pessoa do Papa e o reforço do episcopado; na esfera socioeconômica, a condenação ao comunismo e ao capitalismo e um indisfarçável saudosismo da Idade Média (...); na esfera doutrinária, a retomada das decisões fundamentais do Concílio de Trento (1545-1563), em especial aquelas estabelecidas para o combate ao protestantismo" (MANOEL, 2004, p. 11).

Rev. Caminhos da Educação: diálogos, culturas e diversidades, Teresina, v. 2, n. 1, p. 5-25, jan./abr. 2020 
ordem sociais, sem influência do ethos religioso, que permeara o regalismo até então vigente no Estado brasileiro.

Ainda conforme demonstrado (ANJOS, 2015), para cada um desses grupos, a educação da criança pela família constituiu-se num objeto de disputa, na medida em que, do tipo de formação que a ela fosse dado pelos pais na infância - isto é, uma educação regalista, ultramontana ou liberal - dependeria, em grande parte, a vitória de uma posição - ou representação - sobre as demais. É aí que a definição das cronologias da infância entrou em cena no bojo dos debates mais amplos sobre a educação da criança pela família que essa luta de representações veio a produzir, ao delimitar o corte geracional a ser abarcado pelos modelos educativos então propostos.

Com base nessas considerações introdutórias, é que se delineia o objetivo deste artigo: identificar as representações sobre as cronologias da infância presentes em textos eclesiásticos e jurídicos em circulação no Brasil Império, evidenciando o modo como elas disputavam entre si e eram postas a serviço dos interesses da Igreja e do Estado brasileiros da época, as duas instituições sob as quais se abrigavam ora regalistas (ligados à Igreja e ao Estado), ora ultramontanos (ligados essencialmente à Igreja) e ora os liberais (ligados essencialmente ao Estado).

Dentre os diversos textos que poderiam ser investigados, as fontes escolhidas para inquirição são dois documentos nos quais é possível encontrar, em forma de discursos mais ou menos sistemáticos, uma clara demarcação das cronologias da infância feitas por essas duas instituições e passíveis de serem apropriadas - ou seja, diferentemente interpretadas (CHARTIER, 2002) - pelos três grupos em disputa: as Constituiçoes Primeiras do Arcebispado da Babia e o Abecedário Jurídico de Carlos Antonio Cordeiro.

As Constituições Primeiras do Arcebispado da Babia são fruto de uma tentativa de reforma tridentina no Brasil anterior àquela que seria empreendida pelos Bispos Ultramontanos do Império, conduzida ainda no período colonial por D. Sebastião Monteiro da Vide, então, Arcebispo da Bahia, que, não conseguindo convocar um Sínodo Provincial, "realizou apenas um sínodo Diocesano em 1707, elaborando as Constituições Primeiras do Arcebispado da Babia, primeiro código canônico brasileiro e Rev. Caminhos da Educação: diálogos, culturas e diversidades, Teresina, v. 2, n. 1, p. 5-25, jan/abr, 2020 
único até o fim do Império" (SANTIROCCHI, 2010, p. 200). Esse documento do século XVIII, por ter sua primeira edição considerada esgotada e rara, foi reeditado na Diocese de São Paulo em 1853, com algumas alterações de teor regalista feitas pelo Cônego Ildefonso Xavier Ferreira, garantindo, assim, "atualização” e adequação à política imperial oitocentista, mas, também aos interesses ultramontanos, dado seu originário e indissimulável teor tridentino. Continuou, ademais e em ambos os casos, a reger "todas as dioceses brasileiras durante todo o Período Imperial, sendo constantemente citadas pelos bispos e na legislação civil" (SANTIROCCHI, 2010, p. 200). É justamente por essa imbricação existente em tal documento que tanto o regalismo quanto o ultramontanismo dependeram dele para a delimitação do tempo da infância. A diferença é que no primeiro caso esse documento vinha colocado a serviço daquela mesma submissão da Igreja ao Estado que falei anteriormente, enquanto no segundo, estabeleceria, por meio das apropriações de que seria objeto no discurso dos bispos reformadores do Segundo Império, as interpretações específicas que a Igreja passaria a fazer de questões que, se antes ficavam dependentes do regalismo, agora, passariam a ser de alçada exclusiva da hierarquia eclesiástica ultramontana. Nos limites deste artigo, não nos deteremos nessas apropriações ${ }^{4}$, colocando nossa atenção tão somente nas representações em torno das cronologias da infância que as Constituições, tanto para regalistas quanto ultramontanos, delimitavam.

No âmbito do Estado Brasileiro Imperial, dada uma ausência de um código civil onde as cronologias da infância poderiam ser rapidamente encontradas pelo historiador, somada à consequente dispersão de leis vigentes onde precisaríamos buscá-las - as Leis Extravagantes de Portugal, o Código Filipino, a Constituição Imperial de 1824, o Código Criminal de 1831, as diversas tentativas de Consolidações das Leis Civis, etc. -, optei por identificá-las no Abecedário Jurídico de Carlos Antonio Cordeiro, Bacharel pela Academia de Direito de São Paulo, que editou sua obra em 1858, na mesma década, portanto, da reedição das Constituições, o

\footnotetext{
${ }^{4}$ Remeto, contudo, a Anjos (2017), estudo no qual o leitor poderá acompanhar algumas das apropriações feitas pelo editor da segunda edição das Constituições, o Cônego Ildefonso Xavier Ferreira, em 1853, acerca de outras questões ligadas à educação da criança pela família contidas neste documento e que aqui não serão abordadas.

Rev. Caminhos da Educação: diálogos, culturas e diversidades, Teresina, v. 2, n. 1, p. 5-25, jan./abr. 2020
} 
que torna essas fontes bastante próximas no tempo e no espaço entre si e dos debates aqui investigados. Esse tipo de opúsculo era bastante popular entre juristas e advogados - desde os bancos escolares das Academias Imperiais de Direito até a labuta cotidiana nos tribunais -, funcionando como um pequeno vade-mécum (literalmente, "sempre comigo") das principais leis acerca das questões centrais da prática forense, indicando temas de jurisprudência, a essência legal do termo e as fontes legislativas ou os estudos que o baseavam. Prestava-se perfeitamente para o fim da prática jurídica do passado e, no presente, à prática de crítica historiográfica ao qual pretendemos submetê-lo, não só pela síntese legal que oferece, mas, também, por ser um suporte de circulação de ideias e concepções jurídicas que estariam, posteriormente, na base das posições liberais em matéria de organização do Estado brasileiro e, naquilo que nos interessa, das cronologias da infância.

$\mathrm{O}$ artigo está dividido em três partes. $\mathrm{Na}$ primeira, são delineadas as cronologias da infância presentes nas Constituições e na segunda, as identificadas no Abecedário. $\mathrm{Na}$ terceira parte, a modo de conclusão, são contrastadas as representações identificadas na busca por evidenciar as disputas e concorrências entre elas.

\section{As cronologias de infância nas Constituições Primeiras do Arcebispado da Bahia}

As Constituições são organizadas em cinco grandes partes, denominadas livros, cada uma delas abordando aspectos específicos do direito canônico. É, sobretudo, nos livros Primeiro - que trata, dentre outras, das obrigações dos fiéis católicos - e Segundo - relativo ao Sacrifício da Missa -, que encontramos referências claras a cronologias da infância. Essas vão sendo demarcadas conforme as obrigações e responsabilidades religiosas que recairiam sobre a criança no tempo infantil ou que deveriam ser observadas pelos adultos em relação a elas ou nas suas relações com elas: pais, mães, padrinhos e clérigos. Após uma leitura cruzada das diversas referências às idades da vida encontradas, no quadro abaixo, apresenta-se uma síntese das cronologias da infância presentes nas Constituições: (Quadro 1) 


\begin{tabular}{r|l}
\hline \multicolumn{1}{c|}{ Cronologia } & \multicolumn{1}{c}{ Obrigações da criança ou dos pais e/ou clérigos } \\
\hline Até os 8 dias de vida & Ser levada à pia batismal pelos pais ou responsáveis \\
\hline Até os 7 anos & Levar uma vida cristã, ainda que sem o peso das obrigações \\
\hline Aos 7 anos & Confissão e Confirmação \\
\hline Dos 7 aos 10 anos & Observação das especificidades da infância na confissão \\
\hline Dos 7 aos 12 anos & Última etapa da infância das meninas \\
\hline Dos 7 aos 14 anos & Última etapa da infância dos meninos \\
\hline
\end{tabular}

Quadro 1 - Cronologias da Infância na Legislação Canônica Brasileira Fonte: Constituições Primeiras do Arcebispado da Bahia

Com base no conteúdo identificado nas Constituições, pode-se dizer que, para a Igreja Católica, havia três infâncias: uma que ia até os sete anos de idade, seguida por outras duas: a que começava aos sete anos e chegava até os dez anos, mais ou menos, na qual meninos e meninas, já na idade da discrição ${ }^{5}$, começavam a participar de diferentes momentos da vida da Igreja, mas ainda assim sendo tratados como crianças e a última que, partindo dos dez anos tinha nas diferenças entre os sexos, habilitando-os à vida marital, o elemento demarcador do término do tempo infantil - os doze anos para as meninas e os quatorze anos para os meninos. As balizas dessas infâncias eram construídas com base na recepção dos diferentes sacramentos e participação em algumas obrigações eclesiásticas. Vejamos como cada uma delas era compreendida.

Até no máximo os oito dias de vida, a criança nascida para o mundo, deveria nascer para a Igreja, assim "conformando-nos com o costume universal do nosso Reino [de Portugal, costume que continuou válido no Império Brasileiro], que sejam batizadas até os 8 dias depois de nascidas." (CONSTITUIÇÕES, Tít. XI, \ 36). Dali até os sete anos, já deveriam viver como cristãos no mundo, conquanto não participassem mais pesadamente das obrigações dos cristãos. Chegando aos "anos da discrição, que regularmente são os 7 anos e antes deles tanto que tiver malícia e capacidade para pecar” (CONSTITUIÇÕES, Tít. XXXIV, \139) , meninos e meninas ficavam obrigados à recepção de dois sacramentos: a confissão e a confirmação. Esta última, está dentre os que ordinariamente só

\footnotetext{
${ }^{5}$ Expressão que, para o contexto da produção das Constituições, designaria o momento a partir do qual já era possível "saber o que importava para a salvação da alma, na medida em que significava ter consciência das escolhas" (MONTEIRO, 2005, p. 45). Note-se que não havia consenso em relação ao momento cronológico dessa idade da discrição, como se verá adiante. Entrementes, havia acordo sobre em quê ela consistiria.
}

Rev. Caminhos da Educação: diálogos, culturas e diversidades, Teresina, v. 2, n. 1, p. 5-25, jan./abr. 2020 
se recebem uma vez na vida (os outros são o Batismo, o Matrimônio e a Ordem) e a ordenação do Bispado era de que "quem houver de receber o Sacramento da Confirmação tenha ao menos 7 anos de idade, salvo antes deles houver perigo de morte ou alguma justa causa nos parecer” (CONSTITUIÇÕES, Tít. XXI, \ 77).

Já o Sacramento da Confissão deveria ser mais frequente (no mínimo uma vez ao ano, pela Páscoa da Ressurreição) o que acarretava preocupações da parte dos bispos acerca de como proceder. Tais preocupações revelam que, ao chegar aos sete anos, a criança deveria continuar sendo vista como tal e não como um adulto em miniatura, posto que ainda possuía especificidades que a diferenciavam dos outros penitentes. Por essa razão, as Constituições recomendavam:

\footnotetext{
Exortamos aos párocos que tenham muito cuidado com os de menor idade, que tiverem obrigação de se confessar para os fazerem cumprir com este preceito e lhes mandamos, sob a pena de se lhes dar em culpa e serem castigados gravemente; que os ouçam a cada um per si e não a muitos juntos, ainda que sejam menores de 10 anos porque é grande abuso o contrário: e lhes perguntem pela doutrina cristã e se eles não tiverem pecado, lhes ensinarão coisas proveitosas e necessárias para a salvação e os encaminharão a seguir a amar a virtude e aborrecer o pecado (CONSTIUIÇÕES, Tít. XXXVI, \142).
}

Entre os sete e os dez, anos, portanto, apesar de estarem vivendo a idade da discrição, ainda era preciso levar em conta que a Igreja tinha diante de si crianças, que como tais deviam ser tratadas pelos confessores. Esse é um dado importante, se tivermos presente que é bastante difundido na historiografia da infância brasileira a ideia de que com os sete anos acabaria o tempo infantil, o que a representação eclesiástica não sustenta, chamando-nos a atenção para evitar qualquer afirmação generalizadora nesse sentido. Evidência disso é que, prevendo-se a possibilidade de que os pequenos penitentes não tivessem pecado, o momento da confissão deveria ser aproveitado para uma pequena catequese, ensinando-lhes "coisas proveitosas e necessárias para a salvação" e encaminhando-os "a amar a virtude e aborrecer o pecado". Mesmo no caso das crianças terem pecados a despejar nos ouvidos no sacerdote, a confissão deles devia ser diferenciada pela indagação da doutrina cristã, coisa não prevista quando da administração do sacramento aos adultos. No caso de terem pecado e ser lhes dada penitência, noutro ponto das Constituições sugere-se, Rev. Caminhos da Educação: diálogos, culturas e diversidades, Teresina, v. 2, n. 1, p. 5-25, jan/abr, 2020 
embora implicitamente, que a idade do fiel deveria ser levada em conta: "E antes que se deem as penitências, devem considerar o estado, condição, sexo e idade dos penitentes.” (CONSTITUIÇÕES, Tít. XLII, \173).

Os sete anos, marcavam igualmente na vida de meninos e meninas a obrigação de começar a ouvir missa nos domingos e dias santificados (CONSTITUIÇÕES, Tít. XI, \366). Dessa idade em diante podiam ser prometidos em casamento, através dos “desponsórios de futuro" (CONSTITUIÇÕES, Tít. LXIII, \262) mas, a idade para realização do casamento era definida não mais por um corte etário comum e sim pelas diferenças dos sexos: a partir dos doze anos, somente as meninas já poderiam casar nos termos indicados enquanto os meninos precisariam esperar pelos quatorze anos (CONSTITUIÇÕES, Tít. LXIV, \267). Também era só nessas mesmas idades que meninas e meninos podiam passar a receber o Sacramento da Eucaristia, posto que então já teriam "juízo para entender o que fazem e a reverência que se deve a este Divino Sacramento" (CONSTITUIÇÕES, Tít. XXIV, \ 86) Finalmente, a partir dessas mesmas idades, meninos e meninas poderiam ser alvo, caso incorressem em falta mui grave, da maior e mais radical sanção da Igreja Católica: a excomunhão, que como o próprio nome diz, consiste em privar o fiel da Eucaristia e, com esse gesto, excluí-lo de modo visível da vida eclesial. Assim, na cronologia construída no texto eclesiástico, era ao atingir essas idades, que meninas e meninos, aos olhos da Igreja, deixariam a infância plenamente e passariam às obrigações da vida adulta cristã.

\section{As cronologias de infância no Abecedário Jurídico de Carlos Antonio Cordeiro}

O caminho para identificarmos as cronologias da infância no Abecedário Jurídico de Carlos Antonio Cordeiro difere, em função do gênero e materialidade da fonte, do adotado para interrogarmos as Constituições. Enquanto esta última, como documento canônico, é organizada em livros, títulos, parágrafos e artigos, o Abecedário, como o próprio nome indica, é organizado em verbetes por ordem alfabética. Isso, contudo, não significa que as informações que buscamos sejam obtidas de modo mais Rev. Caminhos da Educação: diálogos, culturas e diversidades, Teresina, v. 2, n. 1, p. 5-25, jan./abr. 
"direto" que na fonte eclesiástica. Antes, parece que será - para falar com Walter Benjamin (1985) - por meio de uma leitura a contrapelo de determinados verbetes, que conseguiremos uma visão mais complexa das representações sobre as cronologias da infância postas em circulação neste impresso.

Se principiarmos pelo verbete $i d a d e$, o jurista nos dá um panorama inicial da questão das cronologias da infância, baseado numa interpretação vinda de um estudo por ele consultado que, embora não tenha conseguido identificar - mas que se assemelha àqueles investigados por José Gondra e António Gomes Ferreira (2006), no âmbito da medicina -, permite uma visão geral de como a questão era, em principio, encarada pelo Estado Imperial.

Idade. A do homem, em rigor, se divide em 7 classes a saber: infância, até os 7 anos; idade pupilar até os 12 anos nas fêmeas e 14 anos nos varões; puerícia até os 18; adolescência até os 25 ; juventude até os 50 e nos mais robustos até os 60 ; senectude até os 80 e daí por diante é idade decrépita (CORDEIRO, 1858, p. 91).

Caso estivéssemos nos guiando pelas semânticas da infância, conforme fez em seu conhecido estudo Carlo Pancera (1994), diríamos que para o discurso jurídico ela terminaria aos 7 anos, como categoricamente parece afirmar nosso bacharel Carlos Antonio. Entrementes, como é o tipo de relações diferenciadas construídas entre adultos e crianças que nos interessa, somos provocados a supor que talvez a infância fosse prolongável ainda por mais um tempo, até os 12 anos para meninas e 14 para meninos, razão pela qual o jurista as designa de idade pupilar, isto é, idade em que ainda se está sob a direção de alguém. Com efeito, se aqui Carlos Antonio Cordeiro é objetivo, vasculhando seu dicionário em busca de verbetes que apresentam cortes etários ${ }^{6}$, vemos que essa hipótese não é de todo ilógica, embora o caminho para verifica-la seja algo tortuoso. Para facilitar (um pouco) a vida do leitor, o quadro a seguir procura sintetizar o que pude descobrir no encalço da referida hipótese: (Quadro 2)

\footnotetext{
${ }^{6}$ Após a leitura minuciosa de todo o Abecedário, os verbetes encontrados contendo indicações cronológico-etárias foram: criar, emancipação, estupro, filho-famílias, menor e menores.

Rev. Caminhos da Educação: diálogos, culturas e diversidades, Teresina, v. 2, n. 1, p. 5-25, jan/abr, 2020
} 


\begin{tabular}{c|l}
\hline Cronologia & \multicolumn{1}{c}{ Obrigações/ relações da criança ou dos pais } \\
\hline Até os 3 anos & Obrigação da mãe de criar o filho de leite \\
\hline Até os 7 anos & "Fim da infância" na ótica de Antonio Carlos Cordeiro \\
\hline Até os 12 anos & Idade pupilar feminina \\
\hline Até os 14 anos & $\begin{array}{l}\text { Idade pupilar masculina } \\
\text { Idade em que inocenta o criminoso } \\
\end{array}$ \\
\hline
\end{tabular}

Quadro 2 - Cronologias da Infância no Abecedário Jurídico de Antonio Carlos Cordeiro (1858) Fonte: Antonio Carlos Cordeiro (1858)

Em termos criminais, por exemplo, até os 14 anos, a idade inocentava o seu autor (CORDEIRO, 1858, p. 91) e o menor de 14 anos não poderia ser julgado criminoso (CORDEIRO, 1858, p. 126). É claro que se pode objetar que isso se dava porque, segundo as leis penais do Império, todos os menores de 21 anos tinham essa idade como atenuante em qualquer crime e pena que dele decorresse (IDEM, ibidem). Mas há que se levar em conta que entre os 14 e os 17 anos, o juiz já poderia impor ao menor penas de cumplicidade de qualquer crime de que fosse acusado (IDEM, ibidem), sugerindo, destarte, que os 14 anos eram, de fato, o termo de um período mais próximo à infância do que da vida adulta, no qual, por ainda não ter pleno domínio de si e dos seus atos, o sujeito que não havia alcançado esse limite etário era como um pupilo, que precisa ser guiado e conduzido em suas ações, sendo incapaz de responder por elas. Claro que questões de sexo também podiam interferir nessa posição. No caso feminino, o defloramento cometido até os 17 anos em mulher virgem era considerado estupro (CORDEIRO, 1858, p. 68), sugerindo que, se na qualidade de criminosa a mulher já poderia responder ao menos como cúmplice, na qualidade de vítima, caso fosse virgem e não tivesse atingido tal idade, a relação jurídica estabelecida era de outra monta.

Casuísmos à parte, detendo-nos apenas no período que julgamos ser aquele da infância, parece plausível considerar que, no discurso jurídico, os 7 anos marcavam o fim de uma etapa que, contudo, podia se prolongar até os 14 anos, em função do tipo de relação que era estabelecida com o sujeito que vivia esta fase da vida. Dentro da ótica liberal, esse tipo de relação era coisa das mais importantes, em face da lógica de direitos e deveres que também justificava esse tipo de tutela sobre os mais jovens (ANJOS, 2015). Entretanto, antes mesmo dos 7 anos haveria um 
outro corte etário, os 3 anos de idade, fase da vida em que a mãe era obrigada a criar o filho somente de leite (CORDEIRO, 1858, p. 40), isto é, em que a amamentação tida com fundamental para a sobrevivência do bebê deveria ser provida pela mãe com os seus próprios recursos (o próprio leite, ou pagando os serviços de uma ama, o que neste caso, poderia implicar em despesa financeira familiar se ela não tivesse pecúlios seus), indicando ser este primeiro triênio da vida período de uma maior fragilidade da criança em que a presença do adulto não só era necessária como indispensável.

Para resumir, a cronologia da infância construída a partir do Abecedário é a seguinte. Até os três anos, a lei via a criança muito próxima da mãe, sendo cuidada e alimentada constantemente por ela. Dali até os sete anos uma lacuna significativa - o que torna compreensíveis as severas críticas de Moncorvo Filho (1927) de que, juridicamente falando, quase nada teria sido feito pela proteção à infância no Brasil durante o Oitocentos - cujo seu termo era, na acepção do Bacharel que nos guia, o fim da infância. Sabemos, entretanto, que para as meninas ela parece que se prolongava até os doze anos, quando acabava a idade pupilar, que para os meninos se daria aos catoræ̧e. Uma exceção, entretanto, talvez estendesse o tempo infantil na vida da menina - entendido como tempo da inocência - fazendo-a alcançar o menino, pois segundo o Código Criminal, tanto ela como ele, até os catorže anos, ainda não poderiam ser julgados criminosos no Império do Brasil.

\section{As cronologias da infância em disputa: a modo de conclusão}

Tendo identificado as representações da Igreja e do Estado acerca das cronologias da infância, cabe uma importante indagação: estariam elas em concorrência? $\mathrm{O}$ quadro seguinte nos ajudará a construir uma resposta: (Quadro 3)

\begin{tabular}{r|l|l}
\hline \multicolumn{1}{c|}{ Cronologia } & \multicolumn{1}{c}{ Igreja } & \multicolumn{1}{c}{ Estado } \\
\hline Até 8 dias de vida & Batismo & Criação de leite pela mãe \\
\hline Até os 3 anos & $\begin{array}{l}\text { Levar uma vida cristã } \\
\text { Sem todas as obrigações }\end{array}$ & \\
\hline Até os 7 anos & $\begin{array}{l}\text { Levar uma vida cristã } \\
\text { Sem todas as obrigações }\end{array}$ & \\
\hline
\end{tabular}

Rev. Caminhos da Educação: diálogos, culturas e diversidades, Teresina, v. 2, n. 1, p. 5-25, jan/abr, 2020 


\begin{tabular}{r|l|l}
\hline Aos 7 anos & Confissão e Confirmação & "Fim da infância" \\
\hline Dos 7 aos 10 anos & $\begin{array}{l}\text { Especificidades da Infância } \\
\text { Confissão }\end{array}$ & \\
\hline Dos 7 aos 12 anos & $\begin{array}{l}\text { Última etapa da infância das } \\
\text { meninas }\end{array}$ & $\begin{array}{l}\text { Idade pupilar feminina } \\
\text { Período de inocência em crimes }\end{array}$ \\
\hline Dos 7 aos 14 anos & $\begin{array}{l}\text { Última etapa da infância dos } \\
\text { meninos }\end{array}$ & $\begin{array}{l}\text { Idade pupilar masculina } \\
\text { Período de inocência em crimes }\end{array}$ \\
\hline
\end{tabular}

Quadro 3 - Sinopse das cronologias da infância nas representações da Igreja e do Estado Imperial Fonte: Constituições Primeiras e Abecedário Jurídico

Num primeiro momento, é digno de nota que as balizas cronológicas da infância praticamente coincidem nas representações da Igreja e do Estado acerca deste tempo da vida da criança. Particularmente os doze anos para meninas e catorz̧e anos para meninos, nas duas demarcações temporais, comparecem como momentos delimitadores do fim do tempo da vida infantil.

As divergências ficam por conta, no caso da Igreja, pelos oito dias em que o pequeno deveria tornar-se filho de Deus pelo Batismo e após os dez anos, quando o sacramento da confissão já poderia ser ministrado sem levar em conta as especificidades dos infantes penitentes. No caso do Estado, as peculiaridades eram os três anos, época em que a fragilidade da criança diminuía um pouco aos olhos dos juristas e o prolongamento da infância feminina, que até os catorze anos não poderia ser incriminada, ainda que sua idade pupilar já tivesse terminado.

Mas, se olharmos com mais atenção essas cronologias, rapidamente observaremos que a Igreja, com suas determinações, preenche todas as "casas" dessa cronologia - catorze anos completos da vida dos meninos e doze da vida das meninas - ao passo que o Estado só o fez em quatro "casas" - mas que, em anos, equivalem não mais que os três primeiros de vida da criança, em que claramente demarca algo a ser feito para ela. Ora, as cronologias da infância só são importantes porque estabelecem a duração do tempo no qual a criança, por ser vista como diferente do adulto, torna-se alvo de uma atenção específica que inclui, dentre outras coisas, a sua educação.

Nesse caso, é evidente que a Igreja, fosse ela regalista ou ultramontana, possuía um "plano” de ação e relação com o sujeito infantil bem mais intenso que 
aquele pensado pelo Estado Imperial. Sobre essa peculiaridade da ação eclesiástica, André Burguière e François Lebrun (1988) já tiveram oportunidade de notar, para o contexto europeu, que, junto do reforço da autoridade paterna, os reformadores tridentinos trouxeram uma ampliação dos deveres dos pais para com os filhos, o que aumentou, em igual medida, a autoridade e presença da Igreja na vida da família. Era esse mesmíssimo movimento que as Constituições, também elas tridentinas, trataram de fazer para o contexto brasileiro setecentista e depois oitocentista. Já as cronologias da infância no âmbito estatal, limitavam-se a se fazer sentir na vida das crianças em momentos nos quais essas ou os que com elas convivessem infringissem regras jurídicas em vigor no Império, haja vista que nas quatro cronologias encontradas, três delas se referem às responsabilidades criminais que podiam ou não ser imputadas ao sujeito infantil e que só emergiriam em contextos de conflitos e tensões - ou, para falar com Jacques Donzelot (1980), de "polícia das famílias" -, enquanto que no mundo religioso essas idades podiam ser percebidas e incorporadas em contextos sacramentais mais amenos e festivos, como o batismo, a confirmação, a primeira comunhão ou o casamento.

Enquanto Igreja e Estado estiveram unidos nos meios a serem seguidos para a educação da criança (sobretudo, no bojo do regalismo), pouca importância essas diferenças de alcance das cronologias da infância tiveram. $\mathrm{Na}$ verdade, elas se reforçavam mutuamente e se complementavam. Mas, no momento em que começaram a divergir entre si nos debates travados entre ultramontanos e liberais, certamente a Igreja, que já estava habituada a servir-se e intervir na vida da criança com frequência, saiu com uma considerável vantagem na concorrência entre as representações das cronologias da infância que investigamos aqui.

É claro que se pode objetar que as coisas não necessariamente tenham sido assim, pois aquela casa dos 7 aos 14 anos, guardadas variações entre as diferentes províncias do Império, seria ocupada pela escola pública, patrocinada pelo Estado, na qual a formação do cidadão poderia ser levada à cabo, numa presença diária talvez até mais intensa que aquela que - num país continente e pouco povoado, no qual as distâncias eram grandes o suficiente para que as crianças só frequentassem os atos da religião, na melhor das hipóteses, semanalmente - a Igreja conseguia exercer. 
Isso seria certo, sem dúvida, se a maioria das crianças que viviam no Império tivessem frequentado uma escola. Mas, como a historiografia tem demonstrado, a realidade era outra e a educação que mais alcançava esses pequenos súditos de D. Pedro II era, de fato, a educação familiar, cujas representações regalista, ultramontana e liberal concorriam entre si. As duas primeiras, em particular, eram informadas por essas cronologias da Igreja. E o catolicismo ultramontano, por sua vez, ao insistir numa vida cristã mais intensa e enquadrada pelo clero (LEBRUN, 2009), na qual a prática dos sacramentos era um dos carros-chefes, conseguia sobrepor-se, ainda, ao regalismo, que embora valorizasse o culto público não se preocupava tanto com as exigências que uma vida piedosa e sacramental impunha a um clero de formação iluminista e mais preocupado com a política que a religião (CARVALHO, 2003).

Como em tudo que diz respeito ao tema das balizas demarcadoras da infância, nada pode ser afirmado em definitivo. Mas o ponto em que essas evidências e interpretações nos trouxeram, sugerem que também em termos cronológicos, tudo colaborava para que igualmente representações divergentes a respeito da educação da criança entrassem em concorrência no que dizia respeito ao tempo da vida infantil, que cada uma delas procurava definir e demarcar. E, neste campo, a Igreja Católica de orientação ultramontana levava sensível vantagem em relação a um Estado em fase de lenta laicização.

\section{Referências}

ANJOS, Juarez José Tuchinski dos. A educabilidade da criança em perspectiva histórica: permanências e contradições. In: GONÇALVES JR., Ernando Brito. (org.). Educação em perspectiva crítica: inquietudes, análises, experiências. Curitiba: Appris, 2016, p. 15-38.

ANJOS, Juarez José Tuchinski dos. Pais e filhos na Provincia do Paraná: uma história da educação da criança pela família (Doutorado em Educação). Programa de PósGraduação em Educação, Setor de Educação, Universidade Federal do Paraná. Curitiba, 2015. 
ANJOS, Juarez José Tuchinski dos. Representações em disputa sobre a educação da criança pela família (Província do Paraná, 1853-1889). Educação e Pesquisa. São Paulo, v. 43, n. 1, p. 199-214, jan.-mar. 2017.

ARIÈS, Philippe. História social da criança e da família. Rio de Janeiro: Zahar, 1978.

BECCHI, Egle; SEMERARO, Angelo. Prefazione. In: Archivi d’infanzia. Per una storiografia della prima età. Milano: Nuova Itália, 2001, p. IX-XVI.

BENJAMIN, Walter. Teses sobre o conceito de História. In: Obras Escolbidas I. São Paulo: Brasiliense, 1985, p. 222-232.

BURGUIÈRE, André; LEBRUN, François. El cura, el príncipe e la família. In: Historia de la familia 2: el impacto de la modernidad. Madrid: Alianza Editorial, 1988, p. $97-162$.

CARVALHO, José Murilo de. A construção da ordem. Teatro das sombras. Rio de Janeiro: Civilização Brasileira, 2003.

CHARTIER, Roger. A bistória cultural: entre práticas e representações. Rio de Janeiro: Difel, 2002.

CONSTITUIÇÕES Primeiras do Arcebispado da Babia. São Paulo: Typographia Dois de Dezembro, 1853.

CORDEIRO, Antonio Carlos. Abecedário Jurídico. Rio de Janeiro: Laemmert, 1858.

CUNNINGHAN, Hugh. Storia dellinfanzia. Bologna: Mulino, 1997.

DONZELOT, Jacques. A polícia das famílias. Rio de Janeiro: Graal, 1980.

GONDRA, José Gonçalves. A emergência da infância. Educação em Revista. Belo Horizonte, vol. 26, n. 1, abr. 2010, p. 195-214.

GONDRA, José Gonçalves; FERREIRA, António Gomes. Idades da vida, infância e racionalidade médico higiênica em Portugal (séculos 17-19). Revista Brasileira de Estudos Pedagógicos. Brasília, v. 87, n. 216, p. 119-134, mai.-ago. 2006.

HEYWOOD, Colin. Uma história da infância: Da Idade Média à época contemporânea no Ocidente. Porto Alegre: Artes Médicas, 2004.

KULHMANN JR., Moysés; FERNANDES, Rogério. Sobre a história da infância. In: FARIA FILHO, Luciano Mendes de (org.). A infância e sua educação. Belo Horizonte: Autêntica, 2004, p. 15-33.

LEBRUN, François. As Reformas: devoções comunitárias e piedade pessoal. In: CHARTIER, Roger (org.). História da vida privada 3: da Renascença ao século das Luzes. São Paulo: Companhia das Letras, 2009, p. 76-112. 
MANOEL, Ivan Aparecido. O pêndulo da História. Maringá: EDUEM, 2004.

MONCORVO FILHO, Arthur. Histórico da proteção à infância no Brasil. Rio de Janeiro: Paulo Ponget, 1927.

MONTEIRO, Alex Silva. A Heresia dos Anjos: a infância na inquisição portuguesa nos séculos XVI, XVII e XVIII (Mestrado em História). Programa de PósGraduação em História, Universidade Federal Fluminense. Niterói, 2005.

OLIVEIRA LIMA, Manoel de. O Império Brasileiro (1822-1889). Brasília: Editora da UnB, 1986.

PANCERA, Carlo. Semânticas da infância. Perspectiva. Florianópolis, n. 22, p. $97-$ 104, 1994.

SANTIROCCHI, Ítalo. Os ultramontanos no Brasil e o regalismo no Segundo Império (18401889). (Doutorado em História). Faculdade de História e Bens Culturais da Igreja, Pontifícia Universidade Gregoriana. Roma, 2010.

VARELA, Julia. Aproximación genealógica a la moderna percepción social de los niños. Revista de Educación. Madrid, n. 281, p. 155-176, 1986. 